\title{
Detection of autoantibodies to neutrophil cytoplasmic antigens
}

R J Lock

\begin{abstract}
Introduction
Indirect immunofluorescence remains the gold standard method for the detection of antineutrophil cytoplasm antibody (ANCA). A recommended method for detection of ANCA by indirect immunofluorescence was described in the First International Workshop on ANCA in 1988 and the approach described here is based on that method. ${ }^{1}$ Increasingly, solid phase assays (enzyme linked immunosorbent assay (ELISA), ${ }^{2}$ radioimmunoassay $^{3}$ ) are being applied for the definition of reactions to specific antigens and for the potential improvement in quantification. Several commercial assays are available for antibodies to myeloperoxidase, proteinase III and $a$ granule extracts. However, standardisation of these solid phase assays remains a problem. ${ }^{2}$
\end{abstract}

\section{Clinical correlations}

Until the discovery of this group of antibodies, there was no specific laboratory method for the investigation of systemic necrotising vasculitis, other than histological examination of biopsy material. In 1982 Davies et al described ANCA in a small group of patients with a necrotising glomerulonephritis. ${ }^{4}$ In 1985 this cytoplasmic staining pattern (classic, c-ANCA) was recognised as

This Broadsheet has been prepared by the author at the invitation of the Association of Clinical Pathologists who reserve the copyright. Further copies of this Broadsheet may be obtained from the Publishing Manager, fournal of Clinical Pathology, BMA House, Tavistock Square,
London WC1H 9 JR

Regional Immunology Service, Blood Services South West, Southmead Road, Bristol, BS10 5ND R J Lock

Accepted for publication 29 July 1993
Table 1 Major disease categories associated with the three major staining patterns

\begin{tabular}{|c|c|}
\hline ANCA pattern & Main clinical groups presenting \\
\hline c-ANCA & $\begin{array}{l}\text { Wegener's granulomatosis } \\
\text { Microscopic polyarteritis } \\
\text { Churg-Strauss syndrome }\end{array}$ \\
\hline p-ANCA & $\begin{array}{l}\text { Microscopic polyarteritis } \\
\text { Classic polyarteritis nodosa } \\
\text { Churg-Strauss syndrome } \\
\text { Idiopathic crescentic } \\
\text { glomerulonephritis } \\
\text { Systemic lupus erythematosus } \\
\text { Rheumatoid arthritis }\end{array}$ \\
\hline Atypical p-ANCA & $\begin{array}{l}\text { Ulcerative colitis } \\
\text { Crohn's disease } \\
\text { Primary sclerosing cholangitis } \\
\text { Autoimmune hepatitis } \\
\text { Primary biliary cirrhosis } \\
\text { Systemic lupus erythematosus } \\
\text { Rheumatoid arthritis }\end{array}$ \\
\hline
\end{tabular}

being associated with Wegener's granulomatosis. ${ }^{5}$ In 1988 a second staining pattern (perinuclear, p-ANCA) was recognised in renal patients with systemic vasculitis. ${ }^{6}$

As well as proving useful in the diagnosis of the necrotising vasculitides, ANCAs have been used to monitor disease activity. ${ }^{57}$

The spectrum of ANCA related disorders was further extended with the description of a third staining pattern associated with ulcerative colitis ${ }^{89}$ and later autoimmune hepatitis. ${ }^{10}$ This third pattern is referred to as atypical pANCA, x-ANCA or "snow drift" pattern. pANCA has also been reported in some connective tissue disorders. ${ }^{11}$ The c-ANCA pattern has retained a reputation for high sensitivity and specificity for necrotising vasculitis, but p-ANCA is much less specific. Several groups have described ANCA positivity in infectious disorders. ${ }^{12} 13$ Bacterial infection may be a particular problem. ${ }^{14}$

The major associations of ANCA with disease are summarised in table 1 .

\section{Indirect immunofluorescence assay}

The assay described below is an immunofluorescence assay for the detection of IgG class ANCA. In certain circumstances it may be desirable to look for other classes of antibody (IgA ANCA in Henoch Schönlein purpura, ${ }^{14}$ IgM ANCA in Kawasaki disease..$^{15}$ In these cases the appropriate second antibody should be substituted. The reagents and equipment required are summarised in tables 2 and 3.

\section{Principle}

In the first instance purified human neutrophils fixed in ethanol are used as the substrate in an indirect immunofluorescence assay. This will permit the detection of c-ANCA. It will also detect nuclear and perinuclear stains. This may be caused by (i) p-ANCA, (ii) antinuclear antibody (ANA), (iii) granulocyte specific ANA (GS-ANA) or a combination of (i) and (ii). Many sera that have p-ANCA have a concurrent ANA. In our laboratory about $30 \%$ of p-ANCA sera fall into this 
Table 2 Reagents used in indirect immunofluorescence assay

(1) Polymorphoprep (Nycomed)

(2) Desiccant: silica gel (BDH)

(3) PBS: dissolve one tablet (Oxoid) in $100 \mathrm{ml}$ distilled water, $\mathrm{pH} 7 \cdot 2-7 \cdot 4$

(4) PBS-BSA: pipette $3 \mathrm{ml} \mathrm{BSA}$ (Boseral, Organon Technica) into $100 \mathrm{ml} \mathrm{PBS,} \mathrm{pH}$ to $7 \cdot 2-7 \cdot 4$

(5) Ethanol fixative: absolute alcohol 100 (Hayman Ltd)

(6) Formalin fixative: $\mathrm{mix} 36 \mathrm{ml}$ formaldehyde, $180 \mathrm{ml}$ acetone (both $\mathrm{BDH}$ ) and $184 \mathrm{ml}$ PBS

(7) Lysing buffer: $8.32 \mathrm{~g} \mathrm{NH}_{4} \mathrm{Cl}$ plus $0.84 \mathrm{~g} \mathrm{NaHCO}_{3}$ (both $\mathrm{BDH}$ ) made to 1 litre with distilled water

(8) Fluorescein isothiocyanate (FITC) conjugated antihuman IgG ( $\gamma$ chain) (Dako Ltd) diluted in PBS Actual dilution varies with batch, typically 1 in $200-1$ in 500

(9) FITC conjugated antihuman IgA ( $a$ chain) (Dako), dilution as for (8) above

(10) FITC conjugated antihuman IgM ( $\mu$ chain) (Dako Ltd), dilution as for (8) above

(11) Mountant: dissolve $2.5 \mathrm{~g} \mathrm{1,4-diazobicyclo[2,2,2]}$ octane (DABCO; $\mathrm{BDH}$ ) in $56^{\circ} \mathrm{C}$ water bath Add $10 \mathrm{ml}$ PBS and adjust to $\mathrm{pH} 8.6$

Table 3 Equipment used in indirect immunofluorescence assay

(1) Cytocentrifuge (Cytospin 2; Shandon)

(2) Fluorescence microscope (Labophot 2; Nikon)

(3) Bench centrifuge (Centra 8; IEC)

(4) $37^{\circ} \mathrm{C}$ incubator (alternatively, a small drying oven set to $37^{\circ} \mathrm{C}$ may be used)

(5) $57^{\circ} \mathrm{C}$ water bath

(6) Magnetic stirrer (optional)

group. It is obviously critical to distinguish among these various patterns. This is achieved by further investigation using formalin fixed neutrophils and by using an alternative substrate for ANA, either rat tissue or HEp2 cells. p-ANCA, an artefactual pattern caused by charge dependent migration of granule components to the nucleus, will present with a cytoplasmic pattern on formalin fixed neutrophils. GS-ANA and ANA will be negative. ANA will be positive against rat or HEp2 cells, whereas GS-ANA and p-ANCA will be negative. This approach is summarised in table 4.

\section{Specimen collection and preparation}

Serum samples are preferred. These should be stored at $4^{\circ} \mathrm{C}$ for up to 72 hours. If sera are to be stored for more than 72 hours

Table 4 Cross table of differential staining patterns seen on indirect immunofluorescence

\begin{tabular}{|c|c|c|c|}
\hline \multirow[b]{2}{*}{ Antibodies } & \multicolumn{3}{|l|}{ Substrate } \\
\hline & $\begin{array}{l}\text { Ethanol } \\
\text { fixed } \\
\text { neutrophils }\end{array}$ & $\begin{array}{l}\text { Formalin } \\
\text { fixed } \\
\text { neutrophils }\end{array}$ & $\begin{array}{l}\text { Rat tissue } \\
\text { or HEp } 2 \\
\text { cells }\end{array}$ \\
\hline $\begin{array}{l}\text { c-ANCA } \\
\text { p-ANCA } \\
\text { ANA } \\
\text { GS-ANA } \\
\text { p-ANCA + ANA }\end{array}$ & $\begin{array}{l}\text { Cytoplasmic } \\
\text { Nuclear/perinuclear } \\
\text { Nuclear/perinuclear } \\
\text { Nuclear/perinuclear } \\
\text { Nuclear/perinuclear }\end{array}$ & $\begin{array}{l}\text { Cytoplasmic } \\
\text { Cytoplasmic } \\
\text { None } \\
\text { None } \\
\text { Cytoplasmic }\end{array}$ & $\begin{array}{l}\text { None } \\
\text { None } \\
\text { Nuclear } \\
\text { None } \\
\text { Nuclear }\end{array}$ \\
\hline
\end{tabular}

before analysis then storage at $-20^{\circ} \mathrm{C}$ or $-70^{\circ} \mathrm{C}$ is preferable. Alternatively, sodium azide to a final concentration of $0.01 \mathrm{~g} / 1$ may be added to samples stored at $4^{\circ} \mathrm{C}$ when the sera will be stable for several weeks. Heat inactivated sera should not be used as both false positive and false negative results can occur. Lipaemic samples and those containing particulate matter should be cleared by centrifugation before testing.

\section{Control sera}

Control sera for p-ANCA and c-ANCA should be titred on ethanol fixed slides with each batch of patient samples (see below). A negative control serum should also be included. At the First International Workshop a c-ANCA reference serum (titre $1 / 320$ ) was made available. ${ }^{16}$ This is now available from the Laboratory of Autoimmune Serology, Statens Seruminstitut, Copenhagen, Denmark. Commercial controls for both c-ANCA and p-ANCA are widely available.

In our experience the between batch coefficients of titre variation are $4.5 \%$ for c-ANCA and $6.6 \%$ for p-ANCA. Membership of an appropriate quality assurance scheme is recommended (for example, the United Kingdom External Quality Assurance Scheme).

Titration on formalin fixed slides is unreliable and is not recommended. For the purpose of defining patterns of reactivity, controls are used at a dilution of 1 in 10 .

\section{Preparation of neutrophil suspension}

Neutrophils are separated from fresh anticoagulated (heparin) blood by density gradient sedimentation.

(1) $3.5-5.0 \mathrm{ml}$ of anticoagulated blood are carefully layered on to $3.5 \mathrm{ml}$ Polymorphoprep (Nycomed) and centrifuged at $450-500 \times g$ for 30 minutes.

(2) The lower leucocyte band, containing polymorphonuclear cells, is harvested and suspended in phosphate buffered saline bovine serum albumin (PBS-BSA) to a final volume of $10 \mathrm{ml}$.

(3) The suspension is centrifuged at 500 $\times g$ for 10 minutes and the supernatant fluid discarded.

(4) Lysing solution is added, mixed gently, and incubated at room temperature for two minutes. This will remove any contaminating red cells.

(5) The suspension is centrifuged as in (3) (above) and the pellet washed twice in $10 \mathrm{ml}$ (PBS-BSA).

(6) The pellet is resuspended in PBSBSA and the leucocyte count adjusted to $0.1 \times 10^{9} / 1$.

\section{Preparation of neutrophil substrate} slides

Using $300 \mu \mathrm{l}$ of the above suspension, make cytocentrifuge preparations according to the 
manufacturer's instructions. The cytocentrifuge is run at $1500 \mathrm{rpm}$ for three minutes. Slides should be rapidly air dried to preserve cell morphology.

A modified cytospin method using clotted blood for the preparation of substrate slides has been described. ${ }^{17}$ Neutrophils are allowed to adhere passively to the slide and are then spread by centrifugation to improve visualisation of the staining patterns. This method permits the relatively rapid production of small batches of slides.

\section{Ethanol fixation}

Slides are immersed in absolute ethanol, previously cooled to $4^{\circ} \mathrm{C}$, for 15 minutes and then rapidly air dried.

\section{Formalin fixation}

Slides are immersed in formalin fixative for exactly 50 seconds, drained, and transferred to absolute ethanol as above.

All slides are stored with desiccant at $-40^{\circ} \mathrm{C}$.

\section{Immunofluorescence screen}

All reagents and samples are allowed to reach room temperature and mixed thoroughly before use.

(1) Remove ethanol fixed slides from the freezer and rapidly transfer to $37^{\circ} \mathrm{C}$ incubator for 15 minutes to dry. It is important to avoid condensation of moisture on to the slides as neutrophil morphology may be distorted.

(2) Prepare 1 in 10 dilutions of test and control sera by dilution in PBS. Note, Wiik ${ }^{1}$ prefers the use of sera diluted 1 in 20 to reduce background, but we have not found this to be a problem with the Dako conjugates.

(3) Apply $100 \mu \mathrm{l}$ of diluted sera to each well on the slides (sufficient to cover the neutrophil preparation).

(4) Incubate in a moist box for $20 \mathrm{~min}$ utes at room temperature. At no time during the following procedure should the preparations be allowed to dry out.

(5) Gently rinse the slides with PBS from a wash bottle, taking care not to disturb the neutrophils with the jet.

(6) Wash the slides by immersion in PBS for 20 minutes. The PBS should be agitated during this time, preferably using a magnetic stirrer.

(7) Remove the slides from the PBS one at a time. Drain excess fluid from each slide and add $100 \mu \mathrm{l}$ of diluted conjugate (Dako) to each well.

(8) Incubate in a moist box for $20 \mathrm{~min}$ utes at room temperature.

(9) Wash as in (5) and (6) (above). Remove excess fluid and apply mountant. Seal under coverslips with nail varnish.

(10) Examine by indirect ultraviolet illumination with standard fluorescein isothiocyanate filters, using $40 \times$ air (or water immersion) objective and $\times 10$ eyepieces.

\section{Immunofluorescence titre for quantification}

All titrations should be performed on ethanol fixed slides. Titration on formalin fixed neutrophils is unreliable and is not recommended.

Serial twofold dilutions in PBS are made of the initial 1 in 10 dilution, to give dilutions of 1 in $20,40,80,160$ and 320 . Where pANCA titres have a concurrent ANA then these dilutions should also be used to titre the ANA. In this case the p-ANCA titre is valid only if it exceeds the ANA titre by at least two dilution steps.

\section{Verification of p-ANCA on formalin fixed neutrophils}

The method is the same as for the immunofluorescence screen above, but substituting formalin fixed slides for ethanol fixed slides.

\section{Interpretation of results}

On ethanol fixed neutrophils c-ANCA stains in a granular pattern with a central accentuation (fig 1). On formalin fixed slides the granularity may be coarser and the central accentuation is less obvious (fig 2). Eosinophils and lymphocytes, when present, do not stain.

On ethanol fixed slides p-ANCA usually shows as a sharply delineated perinuclear stain (fig 3). Note that with very strongly positive sera, the antigens may locate to adjacent cells, mimicking the lymphocyte stain seen in fig 5. On formalin fixed slides, p-ANCA reverts to cytoplasmic stain, similar to that seen for c-ANCA (fig 4). In contrast, ANA stain (fig 5) is abolished by formalin fixation.

There are several other staining patterns that can be detected, the most commonly seen being the atypical p-ANCA associated with serum from inflammatory bowel disease patients (fig 6). Atypical c-ANCA patterns may be seen also in sera from patients with inflammatory bowel disease and some connective tissue disease patients (fig 7). This pattern is sometimes referred to as "flat" cANCA, emphasising that there is no central accentuation.

Atypical c-ANCA patterns may be seen also in some infectious states, although these are usually of low titre (fig 8 ).

\section{Solid phase assays}

Many solid phase assays for the detection of ANCA have been described and the use of these assays is likely to increase. Their theoretical advantages over immunofluorescence are: firstly, that they could be fully quantitative, which would offer a better tool for monitoring therapy; and secondly, that defined reactivity with specific antigens could improve the disease specificity of the assay.

The major antigens associated with ANCA have been well described. The major cANCA antigen is proteinase III. ${ }^{19}$ In the necrotising vasculitides the major p-ANCA 
Figure $1 \quad c-A N C A$ on neutrophils fixed in ethanol in serum sample from a patient with Wegener's granulomatosis. Note central accentuation between the lobes of the neutrophils.

Figure 2 c-ANCA on formalin fixed neutrophils from same serum sample shown in fig 1 .

Granularity is much coarser and central accentuation less obvious.

Figure 3 -ANCA on neutrophils fixed in ethanol in serum sample from patient with microscopic polyarteritis.

Figure 4 - $A N C A$ on formalin fixed neutrophils from same serum sample as shown in fig 3. Staining is similar to that seen in fig

2 , often with a finer granularity.

Figure 5 Perinuclear anti-nuclear antibody on neutrophils fixed in ethanol in serum sample from patient with connective tissue disease. Serum did not stain formalin fixed neutrophils but strongly stained in a perinuclear pattern for nuclei in rat tissue. Note positive "dumbell" nucleus of an eosinophil left of centre and the two brightly positive lymphocytes.

Figure 6 Atypical pANCA on neutrophils

fixed in ethanol in serum sample from a patient with ulcerative colitis. Note broad nuclear outline with poor definition. An unstained eosinophil can be seen top centre.

Figure 7 Atypical ("flat") $c-A N C A$ on neutrophils fixed in ethanol in serum sample from $a$ patient with ulcerative colitis. Stain is very finely granular with no central accentuation.

Figure 8 Atypical $c-A N C A$ showing weak fine granular stain with little or no central accentuation in serum sample from a patient with parvovirus infection. A perinuclear "halo" is visible on some cells. These parvovirus antibodies typically are low titre and transient.
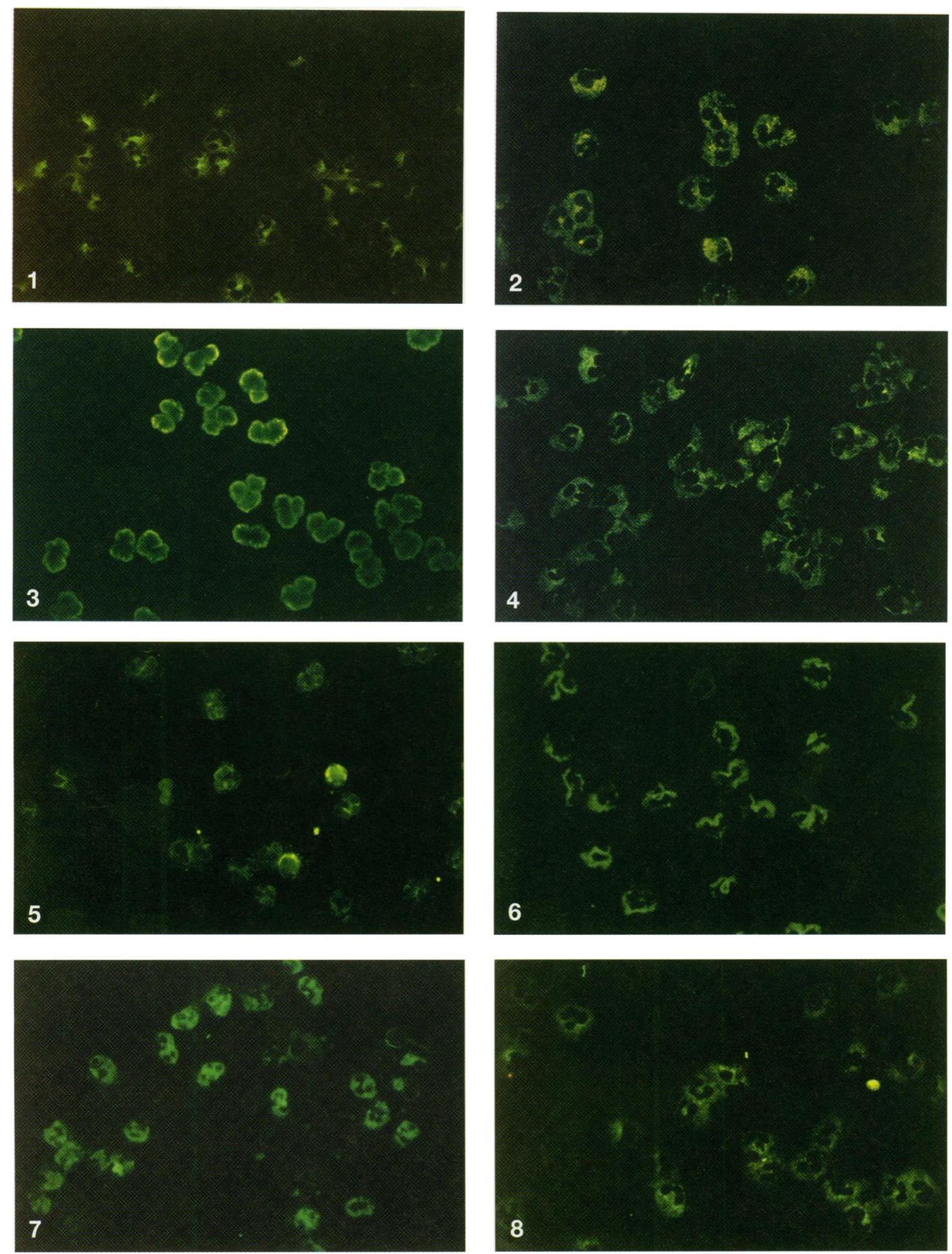

antigen is myeloperoxidase. ${ }^{6}$ Other antigens associated with the p-ANCA pattern include elastase, lactoferrin, and cathepsin G.

There is little evidence to suggest that ELISAs that use crude neutrophil extract as a substrate offer any improvement in sensitivity or specificity over immunofluorescence. Assays for antibodies to the individual antigens, however, offer high specificity, and for myeloperoxidase and lactoferrin, good reproducibility. ${ }^{2}$

Many of the relevant p-ANCA antigens (myeloperoxidase, lactoferrin, elastase, cathepsin $\mathrm{G}, \beta$ glucuronidase, lysozyme) are available from commercial sources and may be used in standard ELISA systems, with the antigen coated directly on to the plate. Purified proteinase III has recently been made available commercially. Kits for antimyeloperoxidase and proteinase III are available. Kits for anti- $a$ granule antibodies are available, but may contain antigens other than proteinase III.

My thanks are due to Drs Tim Wallington and Rebecca Mann for their helpful comments in the production of this graphy. Thanks are also due to Dako Ltd, High Wycombe for their support of the colour reproductions.

1 Wiik A. Delineation of a standard procedure for indirect immunofluorescence detection of ANCA. Acta Pathol Microbiol Immunol Scand 1989;97(Suppl 6):12-13.

2 Hagen EC, Andrassy K, Chernok E, et al. The value of indirect immunofluorescence and solid phase techniques for ANCA detection. A report on the first phase of an international cooperative study on the standardization of ANCA assays. 7 Immunol Methods 1993;159: $1-16$.

3 Savage COS, Winearls CG, Jones S, Marshall PD, manuscript and to Arlene Cordwell for help with the photo- 
Lockwood CM. Prospective study of radioimmunoassay for antibodies against neutrophil cytoplasm in diagnosis of systemic vasculitis. Lancet 1987;i:1389-93.

4 Davies DJ, Maran JE, Niall JF, Ryan GB. Segmenta necrotizing glomerulonephritis with antineutrophil antibody: possible arbovirus aetiology? $\mathrm{Br} M e d \mathcal{f} 1982 ; 285$. 606 .

5 van der Woude FJ, Rasmussen N, Lobatto S, et al. Autoantibodies against neutrophils and monocytes: tool for diagnosis and marker for disease activity in Wegener's diagnosis and marker for disease activi

6 Falk RJ, Jennette CJ. Anti-neutrophil cytoplasmic autoantibodies with specificity for myeloperoxidase in patients with systemic vasculitis and idiopathic necrotizing and crescentic glomerulonephritis. $N$ Engl f Med 1988;318:1651-7.

7 Egner W, Chapel HM. Titration of antibodies against neutrophil cytoplasmic antigens is useful in monitoring disease activity in systemic vasculitides. Clin Exp Immunol 1990;82:244-9.

8 Saxon A, Shanahan F, Landers C, Ganz T, Targan S. A distinct subset of antineutrophil cytoplasmic antibodies is associated with inflammatory bowel disease. $\mathcal{F}$ Allergy is associated with inflammatory

9 Seibold F, Weber P, Klein R, Berg P, Wiedemann K Clinical significance of antibodies against neutrophils in patients with inflammatory bowel disease and primary sclerosing cholangitis. Gut 1992;33:657-62.

10 Snook JA, Chapman RW, Fleming K, Jewell DP. Antineutrophil nuclear antibody in ulcerative colitis, Crohn's disease and primary sclerosing cholangitis. Clin
Exp Immunol 1989;76:30-3.

11 Lesavre P. Antineutrophil cytoplasmic autoantibodies antigen specificity. Am $\mathcal{F}$ Kid Dis 1991;18:159-63.

12 De Clerk LS, Van Offel JF, Smolders WA, et al. Pitfalls with anti-neutrophil cytoplasmic antibodies (ANCA) Clin Rheumatol 1989;8:512-6.

13 Koderisch J, Andrassy K, Rasmussen N, Hartman M, Tiglen W. "False-positive" anti-neutrophil cytoplasmic antibodies in HIV infection. Lancet 1990;i:1227-8.

14 van den Wall Bake AWL, Lobatto S, Jonges L, Daha MR, van Es LA. IgA antibodies directed against cytoplasmic antigens of polymorphonuclear leucocytes in patient with Henoch-Schönlein purpura. Adv Exp Med Biol 1987;216b:1593-8.

15 Savage COS, Tizard EJ, Jayne D, Lockwood CM, Dillon MJ. Antineutrophil cytoplasm antibodies in Kawasak disease. Arch Dis Child 1989;6:360-3.

16 The international serum standard of anti-neutrophil cytoplasm antibodies (ANCA) according to the 1st international workshop on ANCA, 1988. Acta Pathol Microbiol Immunol Scand 1989;97 (Suppl 6):30.

17 Roberts DE, Peebles C, Daggett R Simplified method of preparing neutrophil slides to examine antibodies to preparing neutrophil slides to examine antibodic

18 Roberts DE, Rubin RL Anti-neutrophil cytoplasmic autoantibodies. In: Rose NR, ed. Manual of clinical autoantibodies. In: Rose NR, ed. Manual of clinical
laboratory immunology. 4th edn. Washington, DC: laboratory immunology. 4th edn. Washington
American Society for Microbiology, 1992:781-4.

19 Ludemann J, Utect B, Gross WL. Anti-neutrophil cytoplasm antibodies in Wegener's granulomatosis recognize an elastinolytic enzyme. $\mathcal{F} \operatorname{Exp}$ Med 1990;171:357-62. 